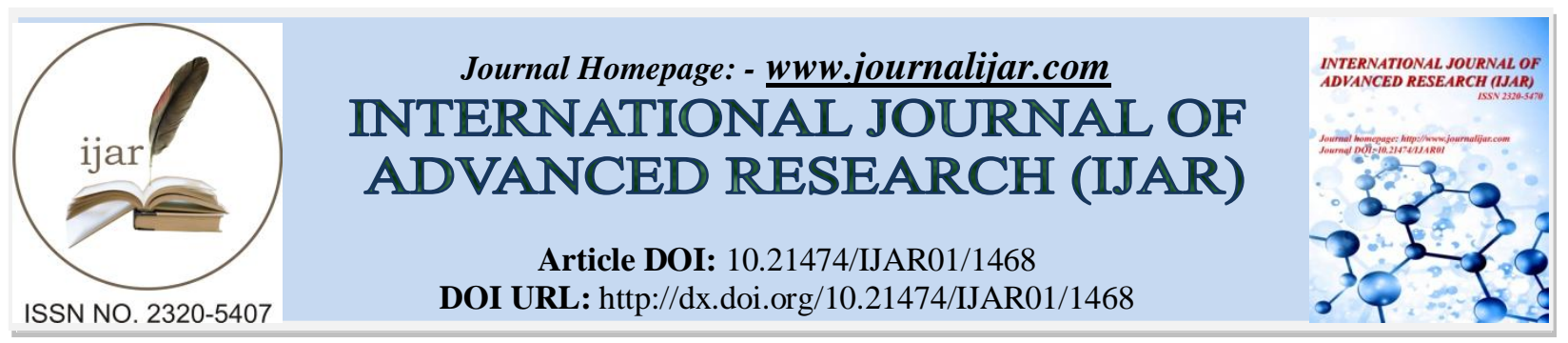

RESEARCH ARTICLE

\title{
SUSTAINABLE DEVELOPMENT AND WATER RESOURCES IN KERALA: AN OVERVIEW.
}

Gayathri Unnikrishnan.

Research Scholar, Centre for Development Studies (CDS), Thiruvananthapuram, Kerala.

\section{Manuscript Info}

Manuscript History

Received: 16 July 2016

Final Accepted: 19 August 2016

Published: September 2016

Key words:-

Sustainable Development, Water Resources, Kerala.

\section{Abstract}

Natural resources like water is essential to ensure human wellbeing and sustainable development. Given the significance of safe drinking water availability, the sustainability of water resources will determine the wellbeing of people in the long run. Here, an attempt was made to understand the condition of water resources and sustainable development in the Indian state of Kerala. It was recognized that serious and sincere measures are required to conserve the water resources- in terms of both quantity and quality.

Copy Right, IJAR, 2016,. All rights reserved.

In its 1987 report, Our Common Future, the United Nations' World Commission on Environment and Development (the Brundtland Commission) defined 'sustainable development' as "development that meets the needs of the present without compromising the ability of future generations to meet their own needs". Winpenny (1997) has suggested the definition of Sustainable Development (SD) in the water sector given by Dubourg, 1994: "the use of water resources which imposes no cost on future generations, such as might arise through depletion of resource or through a reduction in quality". Therefore, it is to be understood that sustainability of water resources, both in terms of quality and physical availability is important for human wellbeing, since human wellbeing is linked to the availability of safe drinking water.

"Clean, accessible water for all is an essential part of the world we want to live in. There is sufficient fresh water on the planet to achieve this. But due to bad economics or poor infrastructure, every year millions of people, most of them children, die from diseases associated with inadequate water supply, sanitation and hygiene. By 2050, at least one in four people is likely to live in a country affected by chronic or recurring shortages of fresh water." Moreover, water directly influences our future, so we need to change the way we assess, manage and use this resource in the face of ever-rising demand and the over exploitation of our groundwater reserves. The planet will face a $40 \%$ shortfall in water supply by 2030 , unless we dramatically improve the management of this precious resource $\mathbf{U N E S C O}(2015)^{2}$.

\footnotetext{
${ }^{1}$ Source: http://www.un.org/sustainabledevelopment/water-and-sanitation

${ }^{2}$ United Nations World Water Development Report(UN-WWDR)
} 


\section{A Profile of Kerala:-}

The state of Kerala was formed on 1 November 1956. Now it has a population density ${ }^{3}$ of 860 . High level of human development was achieved by the state without much economic growth. The unique development experience of Kerala is often referred to as the 'Kerala Model' of development. The human development achievement of the state is comparable to that of the developed countries.

Moreover, the state of Kerala is blessed with plenty of water resources. Kerala has 44 rivers, several ponds, streams, backwaters and lakes. It also receives ample monsoon rains twice in an year, i.e., the South- West and North-East monsoon rains. However, these water resources need to be properly managed and conserved for both the present and future generations. Pollution of surface water and ground water has been reported in the state. Availability of safe drinking water also depends upon the long run sustainability of water sources.

The situation of high Human Development Index (HDI) and trends against the principles of sustainability could be observed in the Kerala economy. For example, the Centre for Excellence in Environmental Economics of Kerala Agricultural University predicts severe water shortage in the state by $2021^{4}$. Mismanagement of natural resources like water in a state like Kerala is a surprising contradiction from the point of view of social engineering. The reckless sand mining and the lowering of ground water level in certain districts in the state are alarming. Such a situation warrants an investigation on the conditions of human development in relation to the concerns of sustainability aspects. Therefore, access to safe drinking water may be considered as one of the components of a good development indicator.

There is an urgent need to incorporate the aspect of environmental sustainability in the assessment of the development path of the state. One of the significant challenges for reaching sustainable Human Development (HD) is the judicious use of natural resources and proper environmental governance. The proper conservation of water as a natural resource in the state of Kerala, assumes utmost significance, as Kerala is considered to be one of the highest rainfall receiving states in India. In this context it is worth re examining the development experience of Kerala, in terms of its performance in human development.

Thus, the over exploitation and deterioration of the natural resources like water is an issue which requires immediate attention, as it is an inevitable factor in achieving sustainable development, and especially 'sustainable human development'. In this context, it becomes necessary to address the emerging challenges to the economy, ecology, and society, that may befall as a consequence of unsustainable practices in managing the water wealth of a region. Thus there is a need to explore how human wellbeing is influenced by availability of and access to safe drinking water, which is an essential attribute of human wellbeing. The long term sustainability of freshwater sources becomes important in this context. The factors affecting water resources and its availability and socio economic consequences of water scarcity in certain regions of Kerala also requires attention.

\section{Drinking Water Availability in Kerala:-}

Surface and ground water resources are the major sources of drinking water in the state. Rivers, streams, ponds, lakes, reservoirs etc. come under the 'surface water' sources. Apart from irrigation requirements of the agriculture sector, the domestic needs of the people are also met from ground water sources. Wells play a significant role in drinking water availability in the state.

To quote the Economic Review of Kerala for 2015, "In Kerala 62 per cent of the households depend on wells for drinking water, 1.4 per cent of houses rely on springs, 0.2 per cent on rivers and canals and 0.7 per cent on tanks, ponds and lakes, exposing themselves to bacterial and chemical contamination. While 0.7 per cent apply hand pumps to draw water, 3.7 per cent are serviced by tube wells...In Kerala 78 percent of the people availed drinking water from their own premises, 14 percent of the people depending upon Near the premises and 8 percent Away from the premises".

\footnotetext{
${ }^{3}$ Per Sq. Km. in 2011.

Source: http://www.censusindia.gov.in/2011census/PCA/PCA_Highlights/pca_highlights_file/kerala/Chapter-1.pdf

${ }^{4}$ Santhosh,K.(July26,2014) 'Kerala headed for water scarcity',The Hindu,Thrishur edtn.
} 
The case of Idukki district of Kerala, where $27 \%$ depend on water 'away from premise' is a situation worse than the national figure of $18 \%$, notes the 2015 Economic Review of Kerala. Another observation was made by the Central Ground Water Board in a 2006 report, that in Kerala, out of the 151 blocks that were assessed, 5 were 'over exploited', 15 were 'critical' and 30 were 'semi critical'. Rest were classified as 'safe'.

With regard to rural drinking water programmes, the Economic Review of Kerala notes that "Many habitations which once came under the "covered" status have been found to slip down to the "partially covered" or even "uncovered" status. As per the Ministry of Drinking Water and Sanitation, Government of India, there are 11883 habitations in Kerala, of which 934 habitations have slipped back in 2011-12. The highest incidence is reported in Thiruvananthapuram at 19 percent, followed by Palakkad at 18 percent and Kasaragod by nearly 14 percent among the total slipped back habitations of the State."

Moreover, the contamination of water sources, largely due to anthropogenic reasons like dumping of wastes and industrial effluents to water bodies, use of chemical fertilizers, etc. lead to quality deterioration. Consumption and use of contaminated water can lead to health issues in humans, like skin diseases, other water borne diseases, etc. "Among the districts, Alappuzha and Palakkad are fluoride affected regions; and Thiruvananthapuram dominated in bacteriological contamination of faecal e-coli. Many cases with multiple contaminations were seen in Palakkad, Thiruvananthapuram, Kollam and Alappuzha.'(Government of Kerala, 2015). All such tendencies which lead to the deterioration/depletion of water resources of the state need to be contained immediately.

The high incidence of water shortages, especially during summer is getting worse. The concerns for water management and conservation reaches people's ears only during such hardships, and once some temporary relief comes with a little rain, we tend to forget the issue. However, unless a sustainable solution is found by encouraging the proper management of water resources of the state, we will continue to face this hurdle. The presence of private drinking water suppliers in the state has to be recognized as an indication of unmet needs and existence of demand for water. The rise of urbanization and the increased demand for water for the population will have to be handled using long term sustainable solutions. Apart from the rise in demand for water from various sectors with the expansion of urban centres, another issue is the dependence on water sources outside the urban areas. Dependence on peri-urban or rural areas for water not only involves higher transportation cost and loss due to leakages, but also a threat to the resource base if the rate of extraction is higher than the natural rate of recharge.

Since ensuring "availability and sustainable management of water and sanitation for all" is one of the sustainable development goals to be achieved by 2030 , the need to preserve the water resource base for the welfare of humanity becomes imperative. Water stress and related problems are most likely to affect the poor and vulnerable more severely, and therefore, there should be efforts to reduce inequality between regions and among different income groups in this regard. Universal and affordable access to drinking water is to be implemented through policies framed on the foundation of the human development, human rights and sustainable development ideals.

\section{References:-}

1. Government of India (2006), Dynamic Ground Water Resources of Kerala (as on March 2004), Central Ground Water Board, Ministry of Water Resources, Faridabad.

2. Government of Kerala (2015), Economic Review 2015, State Planning Board, Thiruvananthapuram,Kerala. http://www.spb.kerala.gov.in/images/er/er15/Chapter4/chapter04.html\#water

3. Government of Kerala (2006), Human Development Report- Kerala 2005, State Planning Board, Thiruvananthapuram.

4. UNESCO(2015),United Nations World Water Development Report 2015, Water for a Sustainable World, France.

\footnotetext{
${ }^{5}$ https://sustainabledevelopment.un.org/?menu=1300
} 